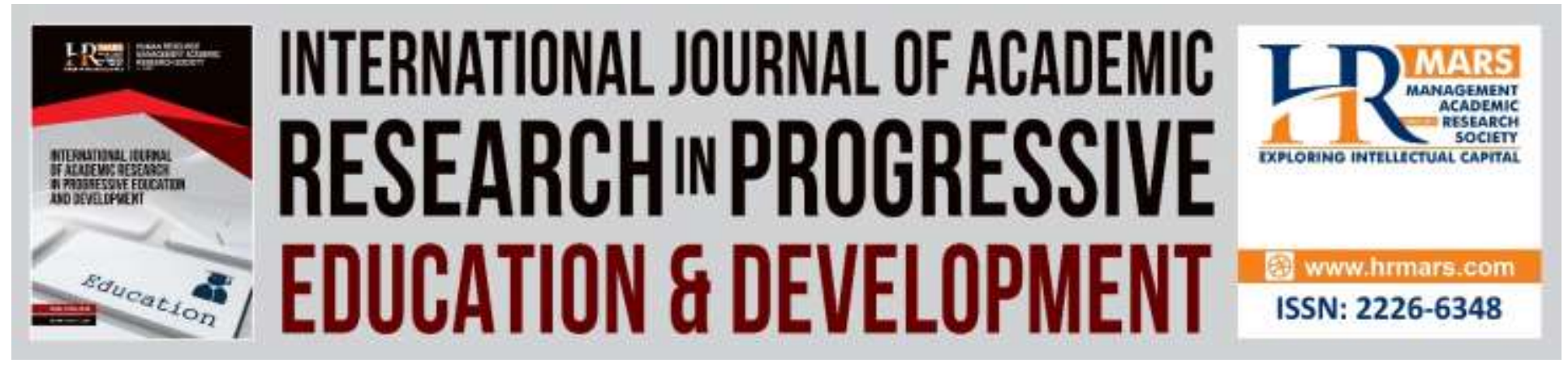

\title{
Elements of Thinking in Teaching Student-Centered Learning on Faith: A Case Study
}

Fatahiyah Elias, Mohd Isa Hamzah and Khadijah Abdul Razak

To Link this Article: http://dx.doi.org/10.6007/IJARPED/v8-i3/6297 DOI: 10.6007/IJARPED/v8-i3/6297

Received: 15 July 2019, Revised: 16 August 2019, Accepted: 01 September 2019

Published Online: 23 September 2019

In-Text Citation: (Elias, Hamzah, \& Razak, 2019)

To Cite this Article: Elias, F., Hamzah, M. I., \& Razak, K. A. (2019). Elements of Thinking in Teaching StudentCentered Learning on Faith: A Case Study. International Journal of Academic Research in Progressive Education and Development, 8(3), 126-132.

Copyright: (C) 2019 The Author(s)

Published by Human Resource Management Academic Research Society (www.hrmars.com)

This article is published under the Creative Commons Attribution (CC BY 4.0) license. Anyone may reproduce, distribute, translate and create derivative works of this article (for both commercial and non-commercial purposes), subject to full attribution to the original publication and authors. The full terms of this license may be seen

at: http://creativecommons.org/licences/by/4.0/legalcode

\section{Vol. 8(3) 2019, Pg. 126 - 132}

http://hrmars.com/index.php/pages/detail/IJARPED

JOURNAL HOMEPAGE

Full Terms \& Conditions of access and use can be found at http://hrmars.com/index.php/pages/detail/publication-ethics 


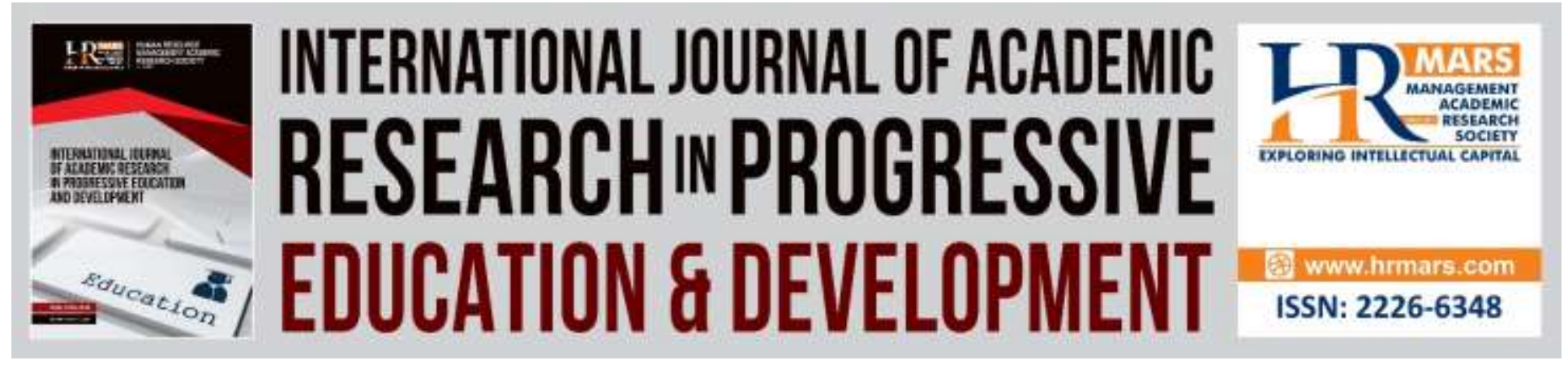

\title{
Elements of Thinking in Teaching Student-Centered Learning on Faith: A Case Study
}

\author{
Fatahiyah Elias, Mohd Isa Hamzah and Khadijah Abdul Razak \\ Faculty of Education, The National University, 43600 Bangi, Selangor, Malaysia
}

\begin{abstract}
The main objective of this study is to examine the practice of thinking skills in student-centered learning lessons taught by Islamic primary school teachers. Along with globalization, thinking skills are important and should be emphasized on young people so that they are vulnerable to the concept of thinking on a high level. Hence, this study is conducted to meet these goals. This study uses qualitative design and case studies. The data collection process uses in-depth interview methods by using semi-structured interviews. The findings were also supported by document analysis. The findings showed that the student-centered learning process in the teaching of the Faith emphasized the element of thinking skills. The emphasis of the thinking element is based on the argument guide from the Quran and the argument of kholqillah. In summary, the practice of thinking skills applied by Islamic Education teachers in learningcentered learning of the Faith students raises students' level of thinking.
\end{abstract}

Keywords: Thinking, Student Centered Learning, Teaching of Faith.

\section{Introduction}

The ability of the mind plays an important role in shaping holistic students (Syaubari \& Yunus, 2017). The usage of common sense optimally is stressed on since the beginnings of Islam. The emphasis on thinking can be proved through expression by Muaz bin Jabal when answering questions relating to the designation of Rasulullah SAW in the matter of the law to be resolved by ijtihad if there is no clear explaination in the Qur'an and the Hadith (Karim, 2006). This was enough to prove the role of the mind which is so important in everyday life applications. Thinking elements is a major transformation that needs to be highlighted in the learning process. In line with this transformation, Higher Order Thinking Skills (HOTS) are matters that are being emphasized in the Ministry of Education Malaysia (Preliminary Blueprint, 2015; Malaysia Organization Education (MOE), 2014). In teaching beliefs in the form of student-centered learning, elements thought to be a key aspect of improving the effectiveness of the process. There are a number of issues of the present, which explains that the lack of elements to think causes learning to be less effective (Syaubari \& Yunus, 2017), less emphasis on the practical aspects (Munawar, 2009) and less emphasis on scientific aspects (Darussalam, 2010, Ibrahim, 2013). In the context of science communication, science and solidarity among Islamic thought 
can form a strong bond. Based on research, to as much as 750 times the words that have the word patio (science) related to the sense of the verses of the Quran. In fact, as much as 49 times the basic reason mentioned in the Quran (Farid, 2013). Clearly proves that thinking skills is one of the key aspects of education within the framework of Islam based on the Quran and the Hadith (Zainoriah, 2015). Therefore, this study was undertaken to explore the elements of thinking skills practiced by teachers of Islamic education in primary school teaching the beliefs in turn can be used as a guide to the future.

\section{Methodology}

The research approach for this study was a single case study with six Islamic Education teachers. For this case study, the issue of thinking in student centered learning was explored through semi structured interviews. Fieldwork was conducted from January 2018 to November 2018. All the interviews were semi-structured and took approximately one to two hours. The interviews were transcribed, coded and organized into themes. To address the validity of this study, multiple sources of evidence were used, leading to methodological triangulation (Bush, 2007 \& Abdul Hamid, 2016). For the interview, the draft case study report was reviewed by the participants; member checking (Bush, 2007; Creswell, 2005). To address reliability in semi structured interviews, due to the deliberate strategy of treating each participant as a potentially unique respondent (Bush, 2007), a case study protocol suggested by Yin (2009) was used.

\section{Findings}

Overall, the data shows that there are five elements in the teaching of thinking in the form of student-centered learning to teach beliefs held by the Islamic education teachers in primary schools generate new ideas, inquiry learning, the implementation of HOTS, had to think about the substance of God and creative in learning.

\section{Theme 1: Generate new ideas}

Generating new ideas is a pattern of thinking element in teaching beliefs in the form of student-centered learning. The approach is carried out to ordinary poor students in order to generate many new ideas. According to the experience Participant 4 (P4), " ... my experience in teaching the lower class students are that they can give and think a lot of ideas..." $(20441,20510)$ - D 6: P4/ 05032018 / TB1. In addition, teachers also emphasize the idea generation skills to students in student-centered learning process. Participant 1(P1) stated that, "... the skills that I think too often we share in our students is that the skill in generating ideas." $(15131,15225)$ - D 24: P1/ 25022018 / TB2. Generate many ideas in student-centered learning is through the interaction of the students in the group. P1 stated again that, "thinking skills sets brilliant ideas in these students." (15404, 15483) - D 24: P1/ 25022018 / TB2. According Participant 7(P7), thinking elements can develop ideas in students to think through their activities. In short, thinking elements in the form of student-centered learning and teaching the faith to help generate new ideas to expand the students of various levels of performance through activities implemented.

Theme 2: The inquiry learning

The next pattern is inquiry learning. Elements of inquiry learning refers to the implementation of this approach that focuses on practice of "Learning by doing" that involves students to carry out activities of exploration, investigation, questioning, reflective thinking and 
the discovery of new knowledge. Elements of thinking in student-centered learning of faith includes two main aspects, namely searching for data and verify the data. P4 stated that, "we want the kind that we make inquiries based. That is why when we use inquiry-based teaching of the faith, it fits perfectly. Inquiries based fits perfectly means that inquiries based have two types of search data, which is both validating data. "(1791: 2007) - D 20: P4/ 10082018 / TB2. The statement explained that the element of thinking needs to be applied in the process of studentcentered learning of the faith. In addition, elements of thinking in inquiry learning also involves questioning. The aim is to tap the information in depth. Indirectly, the students apply the element of thinking. Participant 3(P3) stated as follows;

"Why did you choose that image? Students will tell... what is your view on that image? Last year he told me and he'll even tell you ... what is that? Ask them why ... what is your view of this disabled person? What our actions if we find it? If you were disabled, how do you feel then? Do you want people to despise you? "(9849: 10169) - D 5: P3/ 01032018 / TB1

Theme 3: Implementation of HOTS

Application of higher-level thinking is also an essential element in thinking patterns in student-centered learning. Students emphasized the critical aspects of their learning in the classroom to think analytically and analysis. Example as described by P4;

"Just look at this sin, the sinner where he was in torment. People either place him in paradise. Which do you want to go. ' That analytical thinking. We just asked, 'do you want to go?' we asked only that. 'I want paradise, ustazah' 'why go to heaven? why do you chose heaven? '. 'Paradise is the best.' 'Why the hell do we not want to?', 'This Hell this and that.' So he knew that what he was doing. He's analyzing. "(26 437: 26865) - D 20: P4 /10082018 / TB2

In addition, the application of the elements HOTS is involved in the process of assessing learning. Participant 5 stated that, "he can higher-order think that. He can judge. "(21562, 21617) - D 23: P5 /14082018 / TB1. In the evaluation process, students can also make an appeal variation on something in their learning. According to P4, "He's differentiating" (31 351: 31 372) - D 20: P4/ 10082018 / TB2. Aspects distinguished refers to students can distinguish between good and bad. Theme 4: Thinking about the substance of God

The pattern of thinking is the last element to think about the substance of God. This is important in teaching faith. Essence of God is an aspect that cannot be conceived by man because of the limit of human thinking is limited and different aspects of the substance of God is with men. Therefore, teachers must guide students to think in a student-centered learning teaching faith. According to participant 2 (P2) "We have to think. Inform the students, do not think the point is not the same as to Allah. Allah is different from us". (12840, 12930) - D 3: P2/ 27032018 / TB2. In teaching faith for student-centered learning, teachers should give guidance so that students can thinks in a controlled manner about the substance of God. P2 stated again as follows;

"Don't ever think that our vision is similar to Allah. We have to give them guidelines from that onwards, matters on faith needs to be guided...we can't think of how is Allah? What do we think? We think that how Allah had become. "(4675: 4947) D 4: P2 / 03032018 / TB3

The statement is in line with the opinion of P5 is role in controlling the students to think about the substance of God in order to avoid misunderstandings about the faith they have learned. According P5 are as follows; 
Each one has an idea of each. But is in our control. Security in the classroom is essential. For if our faith is not drive, they might misunderstand the other way around. This kids, even though they are in the lower class, they are still in standard six. (47 459: 47 721) D 23: P5 /14082018 / TB1

\section{Theme 5: Creative learning}

The last theme is detected in the element of thinking in student-centered learning is in a form of creative thinking of students. According to participant 1 (P1) as the following example; "they also express their own creativity in completing the assignment." (5631: 5717) - D 1: P1/ 11022018 / TB1

The theme of students developing creativity is even further explained by P1 as the state of various materials, students will be able to produce products such as mind maps that make up the information on the development of their minds. He explained that as the following statement;

"It's like we give them materials. We give materials. We give them manila cards, other materials and such. It is up to each group on what kind of map they want to produce. Bubble maps, this map and such. Entirely depends on them "(17249, 17480) - D 24: P1 / 25022018 / TB2.

\section{Discussions}

The findings prove the element of thinking is an important aspect that needs to be applied in the learning process. Furthermore, aspect of thinking is emphasized in the Quran and Hadith in which there is a verse that encourages people to think in everyday life (Zainoriah, 2015). Thinking elements in teaching of faith train students to generate a lot of new ideas and implement curiosity (Abdul Said, 2014). Therefore, students have the opportunity to deepen their understanding of the concept of faith more clearly. Thinking elements in the form of studentcentered learning teaching of faith can be applied in inquiry learning. According to Rosnani (2012) pedagogical inquiry learning philosophy is to produce Islamic Education students to think critically and creatively.

In addition, aspects of thinking in learning focused on students to also apply higher-order thinking element (HOTS). In accordance with current requirements, students should be exposed to a learning approach that can train them to think critically, evaluate and analytics. Review by Nursafra et al (2016) also prove critical students starting from a critical teacher of Islamic education. The application needs to be translated via HOTS Islamic education philosophy of education that puts perfection in mind the major thrust in promoting this culture of thinking skills (Syaubari \& Yunus 2017). Implementation of thinking has certain limits. In teaching faith, thinking has restrictions in which to be followed by Muslims to make sure their faith is strong. Thinking about the substance of God is something to be avoided. As the Prophet's hadith that explains, that is, the incidence rose on God and not on the substance of God.

In addition, elements of thinking in student-centered learning can also emphasizes creative learning. Creative not only by students but also creative work on the student feedback on the issues raised by their Islamic Education teachers. This is proved from the study Yusof (2015), all teachers should be creative to make the learning process more meaningful. In short, the themes generated from display elements thought important aspects that should be brought in to strengthen Islamic education pedagogy. 


\section{Conclusion}

The findings show the elements of thinking is an important aspect that needs to be applied in teaching of faith in the form of student-centered learning. It is necessary to generate brilliant ideas in building a brilliant generation. An important aspect is to be shouldered by teachers who act as leaders in the classroom (Hamzah, Asri \& Yusof, 2016). Islamic Education teachers as leaders need to guide students to think in accordance with guidelines can be found in the Quran and Sunnah. It is important that students are protected from deviant teachings. Elements of thinking in the teaching of faith is to be limited to only certain things that relates to events that are evidence of this nature and not on the substance of God. Overall, the elements of the human mind are capable of generating great minds and is on track to think according to the guidelines of the Quran and Hadith.

\section{Corresponding Author}

Fatahiyah Elias, Faculty of Education, National University of Malaysia, fatahiyahelias@gmail.com

\section{References}

Hamid, A. S. ( 2016). Positive and Negative Perceptions on School Marketing: A Case Study of three types of School in England. International Journal of Academic Research in Business and Social Sciences, 224-233.

Karim, A. Z. (2006). Al-wajiz fil usul fiqh. Beirut, Lebanon: Resalah Publishers.

Abdullah, Z. (2011). Teaching and Learning Centered students in Islamic Education at National Secondary Schools in Malaysia. Phd Thesis in Education, National University of Malaysia.

Bush, T. (2007). Authencity in Research-reliability, validity and triangulation. In A.R.J. Briggs, \& Coleman, M, Research Method in Educational Leadership and Management (pp. 91-105). London: Sage Publication.

Noh, C. M. A. (2014). 'Inquiry Approach in Teaching Skills for Islamic Education Thinking: An Analysis'. In Conference on Development of National Level Thinking Skill. Ministry of Education Malaysia: Kuala Lumpur.

Creswell, J. W. (2005). Educational research: Planning, conducting, and evaluating quantitative and qualitative research. Upper Saddle River, NJ: Merrill.

Dagang, M. Y. (2015). The Practice of creativity among Islamic Education Teachers in Johor. PhD Thesis in Education, University of Technology Malaysia.

Darussalam, G. (2010). Islamic Education Pedagogy. Kuala Lumpur: Utusan Publications \& Distributors Sd. Bhd.

Farid, M. (2013). Islamic Thoughts and Thoughts and Challenges. Kuala Lumpur: Institute of Translation \& Book Malaysia.

Hamzah, N., Asri, M. \& Yusof, H. (2016). Teacher Leadership Concept: A Review of Literature. International Journal of Academic Research in Business and Social Sciences, 185-189.

Hashim, R. (2012). Fulfill the Thinking Skills Aspiration in the Malaysia Education Blueprint 20132025 through philosophies and philosophical pedagogy among teachers. Conference of the Dean of the Faculty of Education. Johor Bahru: Universiti Teknologi Malaysia, 1-10. 
Ibrahim, N. A. (2013). Applying Higher Order Thinking Skills (HOTs) in Education Curriculum Implementation: Assessing the Challenges of Teachers of Islamic Education. In Seminar on the Empowerment of Islamic Religious Teaching in Malaysia. Malaysia: Institute of Islamic Understanding Malaysia (IKIM).

Kadri, Z. (2015). Elements of Critical Thinking according to the Al-Quran Perspective: Surah ArRum Review. PhD Thesis in Education, University of Malaya.

Zhaffar, M. N., Hamzah, M. I., Razak, A. K. \& Abdullah, W. A. A. (2016). Towards Islamic Education Teacher of Critical Thinker. Journal of Humanika Sciences, 9-15.

Munawar, A. (2009). The Influence of the Faith on the Behavior of Citizenship of National Secondary Schools in Malaysia. PhD Thesis in Education, National University of Malaysia.

Said, A., Yusof, M., Mohamad, B., Zain, S., Shuhaimi, M. \& Talip, R. (2014). Thinking of Thinking Skills. News.

Syaubari, M. \& Yunus, A. (2017). Issues and Problems in High Order Thinking Skills (HOTS) in Teacher's Practice Practice According to Ibn Khaldun's Views. Journal of Human Capital Development, 1-18.

Yin R. K. (2009). Case Study Research, Design and Methods, Applied Social Research methods Series, 5, 4th Ed. California: SAGE Inc:Thousand Oaks. 